\title{
The Origin of the Covid-19 Pandemic: Legal Obligations of China under International Law
}

\author{
Dr. Arif Jamil*
}

\section{Introduction}

Covid-19 is an outbreak of an infectious (human to human) disease that has reached the status of pandemic. It has spread all over the world and has claimed thousands of lives. Covid-19 comes as a new strain of Corona virus with no cure available, at the time of writing this article. The scientific community bears the pressure of finding a cure or vaccine for the virus. ${ }^{1}$ However, many countries lack the infrastructure and preparedness for tackling this ever fast spreading infectious disease. Most of the developing and least developed countries do not provide free healthcare for the noncommunicable diseases. It is necessary to keep in mind that bio-safety is one of the most crucial matters in the modern age. Thus, this article investigates the proximate cause of the outbreak and emphasizes the necessity of pandemic preparedness for a country. There are different views regarding the origin and spread of the Covid-19. The popular views regarding the origin of this Covid-19 virus are: zoonotic transmission (transmitted from wildlife to human) and a lab-escape, though there lacks credible evidence as to the source of this pandemic. The article meticulously analyses facts surrounding the outbreak in the probable "country of origin" and looks for the "patient zero". 2 Furthermore, the article also emphasizes the legal and international obligations of the country of the origin of the pandemic. Finally, it suggests some recommendations useful for the policy-makers to better prepare for an infectious disease outbreak of any scale.

\section{The Covid-19 Pandemic and some Observations}

The World Health Organization (WHO) describes pandemic as "the worldwide spread of a new disease". ${ }^{3}$ The U.S. Department of Health and Human Services defines pandemic as "[a]n epidemic of disease, or other health condition, that occurs

Associate Professor, Department of Law, University of Dhaka, Bangladesh.

1 The world must admit that the academics, researchers and scientists belong to a disproportionately lower income group than musicians and actors (in some countries) and sports stars.

2 Danny De Vaal, 'What is Patient Zero? Why is it Important to Find Patient Zero in an Outbreak and is There Any Previous Examples?' The Sun (UK Edition, 26 March 2020) <https://www.thesun.co.uk/news/5878645/patient-zero-meaning-disease-outbreak-viral-bacteria/> accessed 29 August 2020 ("Patient zero is a term used to describe the first human infected by a disease.").

3 World Health Organization, 'What is a Pandemic?' (Emergencies preparedness, response, 24 February 2010) <https://www.who.int/csr/disease/swineflu/frequently_asked_questions/ pandemic/en/> accessed 2 April 2020. 
over a widespread area (multiple countries or continents) and usually affects a sizeable part of the population." ${ }^{4}$ However, bio-threats are persistent, emerging and recurring, as interaction between humans and other life forms are obvious on the earth. There are multiple risk factors that give rise to a pandemic. Nita Madhav et al. (2018) observed: "Pandemic risk is driven by the combined effects of spark risk (where a pandemic is likely to arise) and spread risk (how likely it is to diffuse broadly through human populations)." "shattered mental health of the population" to "a grim economy of a country", and the depression can be persistent for a long period of time.

Regarding the infection source of this novel Corona virus, a publication by the Tianjin Municipal Office of the Cyberspace Affairs Commission, We Doctor's Digital General Hospital and China Press of Traditional Chinese Medicine stated:

The infection source of 2019-nCoV has not yet been found. The gene sequence of 2019-nCoV is similar to the SARS coronavirus. However, SARS coronavirus has been proved to stem from the coronavirus that wild animals (bats) carry. At present, most cases admitted have exposure history of "Huanan Seafood Market," where the wild animals were sold, and vendors and customers there have [had] the chance to be in contact with wild animals-carried coronavirus. ${ }^{6}$

The fact that first few patients in China had exposure history of "Huanan Seafood Market,"7 does not automatically offer any theory that the virus was transmitted from wild animal to human. A zoonotic spark causing transmission of the "pathogen of animal origin" to "human population" is not evident from the available facts. However, all zoonotic sparks do not cause massive spread (transmission from animal to human and or human to human) of the pathogen resulting to a pandemic. Nita Madhav et al. (2018) reported:

Most zoonotic pathogens are not well adapted to humans (stages 2-3), emerge sporadically through spillover events, and may lead to localized outbreaks, called stuttering chains (Pike and others 2010; Wolfe and others 2005). These episodes of "viral chatter" increase pandemic risk by providing opportunities for viruses to become better adapted to spreading within a human population. ${ }^{8}$

4 U.S. Department of Health and Human Services, Understanding HIV/AIDS Glossary Pandemic <https://aidsinfo.nih.gov/understanding-hiv-aids/glossary/545/pandemic> accessed 2 April 2020.

5 Nita Madhav and others, 'Pandemics: Risks, Impacts, and Mitigation' in Dean T. Jamison and others (eds), Disease Control Priorities: Improving Health and Reducing Poverty (3rd edn, The World Bank 2018) 316.

6 We Doctor Tianjin Digital Hospital, 'Handbook of Prevention and Treatment of the Pneumonia Caused by the Novel Coronavirus (2019-nCoV)' China Daily (Global Edition, 03 February 2020) <https://www.chinadaily.com.cn/a/202002/03/WS5e380559a31012821727483d.html> accessed 31 March 2020.

ibid.

$8 \quad$ Nita Madhav and others (n 5) 319. 
Further investigation needed to learn how well a pathogen like Covid-19 can transmit from animal to human to result to an accidental zoonotic spark. Kristian G. Andersen et al. (2020) claimed that natural selection might be behind the spark of the infection and they rule out the possibility of the virus being a "laboratory construct" and their publication stated: "It is possible that a progenitor of SARS-CoV-2 [Covid-19] jumped into humans, acquiring the genomic features [...] through adaptation during undetected human-to-human transmission." ${ }^{\text {"9 }}$ Kristian G. Andersen et al. (2020) also warned:

Basic research involving passage of bat SARS-CoV-like coronaviruses in cell culture and/or animal models has been ongoing for many years in biosafety level 2 laboratories across the world, and there are documented instances of laboratory escapes of SARS-CoV. We must therefore examine the possibility of an inadvertent laboratory release of SARS-CoV-2 (FN omitted). ${ }^{10}$

However, according to Kristian G. Andersen et al. (2020), "no animal coronavirus has been identified that is sufficiently similar to have served as the direct progenitor of SARS-CoV-2, the diversity of coronaviruses in bats and other species is massively under sampled." 11 So, there is a group of people in the scientific community who believe in "natural selection" theory, ${ }^{12}$ but this theory is also an assumption ${ }^{13}$ based on inconclusive evidence.

About the publication of Vineet D Menachery et al. (2015), Nature News's editors wrote the following note: "We are aware that this story is being used as the basis for unverified theories that the novel coronavirus causing COVID-19 was engineered. There is no evidence that this is true; scientists believe that an animal is the most likely source of the coronavirus." 14 There is actually no proven theory (scientifically proven and accepted by the world) regarding the source of the infection of Covid-19, at the time of this writing. The only "Wuhan-virus (Covid-19) genome study results" available (Xintian Xu et al. (2020)), was conducted by China, not by

9 Kristian G. Andersen and others, 'The Proximal Origin of SARS-CoV-2' (2020) 26(4) Nature Medicine 450, 451.

10 ibid, 451-52.

11 ibid, 451.

12 ibid, 450.

13 In their (Kristian G. Andersen and others) language: "[M]ost likely the result of natural selection" [emphasis added]. ibid.

Kristian G. Andersen and others concluded: "[W]e propose two scenarios that can plausibly explain the origin of SARS-CoV-2: (i) natural selection in an animal host before zoonotic transfer; and (ii) natural selection in humans following zoonotic transfer." ibid.

14 Declan Butler, 'Engineered Bat Virus Stirs Debate over Risky Research' Nature (12 November 2015) <https://www.nature.com/news/engineered-bat-virus-stirs-debate-over-risky-research1.18787\#/b1> accessed 24 April 2020 (Editors' note, March 2020). 
any independent outsider scientists. However, it is beyond doubt that countries have failed miserably in the containment of the spread of the infection.

Furthermore, the elderly age group seems to be the most vulnerable patient population with higher rate of mortality. Robert Verity et al. (2020) reported:

It is clear from the data that have emerged from China that case fatality ratio increases substantially with age. Our results suggest a very low fatality ratio in those under the age of 20 years. As there are very few cases in this age group, it remains unclear whether this reflects a low risk of death or a difference in susceptibility, although early results indicate young people are not at lower risk of infection than adults. (FN omitted) ${ }^{15}$

\subsection{Patient Zero in China, Italy, France, Iran and the USA}

The Economic Times reported: "Wei Guixian, as identified by The Wall Street Journal, was selling shrimps at the Huanan Seafood Market on December 10 [of 2019] when she developed a cold."16 Though she is considered as the patient zero by many sources, for this Covid-19 in China and the world, she might not be the real patient zero, as the available data on this outbreak are rather conflicting. China News Service (CNS) reported:

[A]ccording to a study by Chinese researchers published in The Lancet on January 24 [of 2020], the first patient presented symptoms consistent with COVID-19 on December 1 [of 2019] and had no exposures to the market.

It is also unclear whether Wuhan is the real ground zero of the deadly outbreak after all. China's top epidemiologist Zhong Nanshan said recently at a press conference that there is no evidence showing that COVID-19 originated in Wuhan. ${ }^{17}$

Jackson Rayan reported: "[T] he very first patient identified had not been exposed to the market, suggesting the virus may have originated elsewhere and been transported to the market, where it was able to thrive or jump into new hosts - whether human or animal." ${ }^{18}$ Furthermore, Josephine Ma reported: "According to the government data seen by the Post, a 55 year-old from Hubei province could have been the first

15 Robert Verity and others, 'Estimates of the Severity of Coronavirus Disease 2019: A Model-Based Analysis' (2020) 20(6) The Lancet Infectious Diseases 669, 676.

16 'A Wuhan Shrimp Seller Identified as Coronavirus 'Patient Zero' The Economic Times (30 March 2020) <https://economictimes.indiatimes.com/news/international/world-news/wuhan-shrimp-selleridentified-as-coronavirus-patient-zero/articleshow/74870327.cms> accessed 2 April 2020.

17 Gu Liping (ed), 'COVID-19 'patient zero' may remain an unsolved mystery' Ecns.cn (25 March 2020) <http://www.ecns.cn/news/society/2020-03-25/detail-ifzusrwx0577281.shtml> accessed 5 April 2020. Ecns.cn is the official English-language website of China News Service (CNS), a statelevel news agency sponsored and established by Chinese journalists and renowned overseas Chinese experts on October 1, 1952.

18 Jackson Rayan, 'Coronavirus explained: Symptoms, lockdowns and all your COVID-19 questions answered' (CNET, 17 April 2020) <https://www.cnet.com/how-to/coronavirus-explained-symptomslockdowns-and-all-your-covid-19-questions-answered/\#wherefrom> accessed 18 April 2020. 
person to have contracted Covid-19 on November 17. From that date onwards, one to five new cases were reported each day." 19

Patient zero in Italy and the spread of the infection seems to be quite a story. Two Chinese tourists were detected on 29 January, 2020 as Italy's first Covid-19 case. $^{20}$ The health authority failed to take notice of the "the first locally transmitted case in Italy", ${ }^{21}$ when on "18 February, a 38 -year-old man went to the [...] hospital in the sleepy northern town of Codogno"22 with corona virus like symptoms but he was allowed to return home. However, the infection might had been spreading for quite a while around that time without being detected or reported. Only those two dates mark as the important events. Other infections spreading around those dates seem to be likely and remained unnoticed. Furthermore, there are claims suggesting that "the coronavirus reached Italy from Germany". ${ }^{23}$ China News Service (CNS) reported:

Massimo Galli, director of the Biomedical Research Institute, told Reuters that the epidemic probably started well before Italy's "patient one" fell ill. By analyzing genetic sequencing of the virus, Galli's team in Milan found evidence suggesting that the virus was brought to Italy by someone infected in the German city of Munich between January $19-22 .{ }^{24}$

Just "twenty days after the first locally transmitted case, authorities had confirmed 12,462 cases, 827 people had died and 1,028 were in intensive care units." ${ }^{25}$ Italian politicians took this outbreak very lightly and they thought it was not a serious virus. The Wuhan experience was totally ignored. Alessio Perrone reported: "Lombardy governor Attilio Fontana (of the far-right League) told the regional parliament the coronavirus was "just a little more than normal flu" on February 25 [of 2020]." ${ }^{26}$ Other politicians went on to celebrate life when Italy was approaching a precarious pandemic. Politician Nicola Zingaretti ${ }^{27}$ had "a public aperitivo [supper] in Milan"28 and "[t]he mayor of Milan Giuseppe Sala [...] launched a campaign called "Milan doesn't stop", encouraging the Milanese not to be afraid. ${ }^{29}$ Just a few weeks later, Italy counted thousands of deaths from the Covid-19 infection. The mortality rate in Italy is

19 Josephine Ma, 'Coronavirus: China's First Confirmed Covid-19 Case Traced Back to November 17' South China Morning Post (International Edition, 13 March 2020). <https://www.scmp.com/news/ china/society/article/3074991/coronavirus-chinas-first-confirmed-covid-19-case-traced-back > accessed 18 April 2020. Alessio Perrone, 'How Italy became the Ground Zero of Europe's Coronavirus Crisis' (Wired, 14 March 2020) <https://www.wired.co.uk/article/coronavirus-italy> accessed 5 April 2020. ibid.

ibid.

ibid.

Gu Liping (ed) (n 17).

Alessio Perrone (n 20).

ibid.

Within few days he was diagnosed positive for Covid-19. ibid.

ibid.

ibid. 
comparatively higher than other countries with similar health systems and some suggests the reason being the elderly (aged 65 or above) population makes up the 22.6 percent $^{30}$ of the total population. However, Alessio Perrone, while quoting Nino Cartabellotta, ${ }^{31}$ explained the reasons why the early outbreak in Italy went unnoticed:

There could be different reasons why these initial contagions were not spotted. "One, it could be that some suspected pneumonia cases were not tested [for coronavirus]," For example, reports emerging in Italian media suggest that hospitals in the outbreak area observed unusually high numbers of pneumonia cases one month before the outbreak. (These have not been confirmed as coronavirus cases yet.)

"Two, it could be that there weren't any severe cases, that they only emerged in a clinically mild way," "and three, it depends on the level of attention that health policies place on [finding] the coronavirus.",32

The first few cases in France were related to Wuhan. Sibylle Bernard Stoecklin et al. (2020) reported:

Case 1 was a 48-year-old male patient living in France. He was travelling for professional reasons in China $[\ldots]$ including Wuhan when he experienced his first symptoms [...] on 16 January. He flew back to Bordeaux, France on 22 January via Shanghai, Qingdao and Paris Charles de Gaulle airports. [...]. He sought medical attention from a general practitioner on 23 January, where he was suspected of COVID-19[...]. Infection was confirmed on 24 January by the National Reference Centre [....].

The patient arrived in Wuhan on 13 January, did not report any visit to markets, exposure to live animals or contact with sick persons during his stay. [...].

Case 2 was a 31-year-old Chinese male tourist who had left Wuhan on 18 January and arrived in Paris on 19 January. [...]. Case 3 was a 30-year-old Chinese female tourist who travelled with Case 2. [...]. On 24 January, they were advised by the Chinese embassy to seek medical attention at the national hotline (SAMU-centre 15) and were immediately transferred to a regional referring hospital [...]. Infection with SARS-CoV-2 was confirmed on 24 January for both of them by the National Reference Centre (Figure).[...].

Neither of the two cases reported any visit to markets, exposure to live animals or contact with sick persons during the 14 days before symptom onset. Both visited a hospital in Wuhan on 16 January for an unrelated medical condition in Case $3[\ldots]^{33}$

These initial three cases confirmed on 24 January in France, are known to be the first cases of novel Corona virus in the Europe. ${ }^{34}$ China News Service (CNS) reported that, "[t]he first confirmed case of coronavirus [January 20, 2020] in the U.S. was

ibid.

President, GIMBE Foundation.

ibid.

33 Sibylle Bernard Stoecklin and others, 'First Cases of Coronavirus Disease 2019 (COVID-19) in France: Surveillance, Investigations and Control measures' (2020) 25(6) Euro Surveillance 1, 4.

34 ibid 1. 
[...] [a] 35-year-old man from Washington state, who came back from Wuhan" ${ }^{\prime 35}$ and "an unnamed merchant from Qom who traveled to China regularly for work, was believed to be the country's [Iran] potential patient zero, according to Iran's health minister Saeed Namaki." ${ }^{36}$

The outbreak seems to have assume its enormous proportions by the end of the January 2020. It had reached many countries by the end of January. During February 2020, the containment seems to have been less effective. In March 2020, the Covid-19 pandemic went global. Some of the infected countries (France, Iran, USA) at the initial stage have traced its infection origin among the travelers from Wuhan or China. However, findings from the "sewage water study" in Spain and Italy leads the search for the origin of the outbreak to a different direction. Catalan News reported: "A study led by the University of Barcelona (UB) has detected the presence of SARS-CoV-2 in wastewater samples from Barcelona on March 12, 2019."37 This study result indicates the presence of the virus before China reported its first case. Liu Caiyu reported: "The presence of COVID-19 in Spain's sewage offers a clue on the virus' existence, either in people or animals, before China reported its first COVID-19 patient in December 2019, Chinese experts said, after Spain detected the presence of the novel coronavirus in March last year, and Italy made similar findings. ${ }^{, 38}$

\section{Dr. Ananya Mandal wrote:}

Italian researchers have found traces of the novel coronavirus SARS-CoV-2 in sewage wastewater that indicates that the virus may have been in circulation since December 2019. This controversial discovery shows that even before the first case was reported in Wuhan, China, in late December 2019, the virus had already arrived in northern Italy. ${ }^{39}$

\subsection{The Outbreak in China and Reporting Issues}

Dr. Li Wenliang, the ophthalmologist from Wuhan (epicenter of the outbreak in China), who shared the news of the outbreak with his colleagues, were harassed on

\footnotetext{
Gu Liping (ed) (n 17).

ibid.

37 Catalan News, SARS-CoV-2 detected in Barcelona water study from March 2019 (26 June 2020) $<$ https://www.catalannews.com/society-science/item/sars-cov-2-detected-in-barcelona-water-studyfrom-march-2019> accessed 22 August 2020. The Catalan News Agency (CNA) is a news agency owned by the Catalan government. Barcelona is the capital and largest city of the autonomous community of Catalonia, as well as the second most populous municipality of Spain.

38 Liu Caiyu, 'COVID-19 in Spain Sewage Brings Origin of Virus a Step Closer' The Global Times (27 June 2020) <https://www.globaltimes.cn/content/1192756.shtml> accessed 22 August 2020.

39 Ananya Mandal, 'Italy's Sewage Water Shows SARS-CoV-2 Presence Prior to Reported Outbreak in Wuhan' News-Medical.Net (20 June 2020) <https://www.news-medical.net/news/20200620/ Italye28099s-sewage-water-shows-SARS-CoV-2-present-prior-to-reported-outbreak-in-

Wuhan.aspx> accessed 29 August 2020 ("A report was released this week on the findings of this analysis of sewage water from various water treatment plants. From the samples obtained in Milan and Turin on the $18^{\text {th }}$ of December 2019, the team found the presence of the SARS CoV-2.").
} 
allegations of spreading rumor and disrupting the law and order. ${ }^{40}$ The Guardian reported:

Li had posted to a group chat with other medics about some patients showing signs of a new Sars-like illness in early December, well before Chinese authorities admitted to the outbreak of a novel coronavirus.

Police detained $\mathrm{Li}$ a few days later for "spreading false rumours" and forced him to sign a police document admitting that he had "seriously disrupted social order" and breached the law. Officers said eight people had been disciplined for spreading rumours in relation to the virus $[\ldots]^{41}$

This incident suggests that local authorities in China suppressed the news of the outbreak in Wuhan at the inception. The Chinese official report on Li's death ${ }^{42} \mathrm{did}$ not accuse him of disrupting public order but they 'maintained that $\mathrm{Li}$ had not verified the information before sending it, and it was "not consistent with the actual situation at the time". ${ }^{43}$ The Chinese authority should have taken Li's observations seriously and focus on containment of the outbreak.

The publication by Xintian Xu et al. (2020) ${ }^{44}$ was accepted for publication on January 16, 2020. It stated: "[N]o obvious evidence of human-to-human transmission was reported". ${ }^{45}$ It seems from the available facts that there should not be doubt regarding human to human transmission in the second week of January 2020.

China's performance on containment of the disease and prevention of the new infection in the subsequent months, e.g., 1st week of April, show how highly capable China is as a nation in containing the spread of an infectious disease. Why did it underperform in the initial weeks of the outbreak? China admitted certain failures of the concerned departments in Wuhan: "slow in response, lost control in the prevention process and ignorant of their job duties during the epidemic." $" 46$

When the first "reported outbreak" happened in Wuhan, China, it continued to spread, as a "human to human transmission". The pandemic could have been averted by imposing a timely lockdown. Instead of preventing the spread of the infection and

40 'Chinese Inquiry Exonerates Coronavirus Whistleblower Doctor' The Guardian (International Edition, 20 March 2020) <https://www.theguardian.com/world/2020/mar/20/chinese-inquiryexonerates-coronavirus-whistleblower-doctor-li-wenliang> accessed 8 April 2020.

(1)

He contracted the virus and died subsequently.

Chinese Inquiry Exonerates Coronavirus Whistleblower Doctor (n 40).

44 Xintian Xu and others, 'Evolution of the Novel Coronavirus from the Ongoing Wuhan Outbreak and Modeling of its Spike Protein for Risk of Human Transmission' (2020) 63(3) Science China Life Science 457, 457-60.

45 ibid 457 ("One genome sequence (WH-Human_1) of the Wuhan CoV was first released on Jan 10, 2020, and subsequently five additional Wuhan CoV genome sequences were released").

46 'Wuhan Police Apologize for Reprimanding Doctor who Sounded Early Alarm on COVID-19 (CTGN, 20 March 2020) <https://news.cgtn.com/news/2020-03-19/Admonition-letter-to-Dr-LiWenliang-improper-investigation-OZvG7i94Fa/index.html> accessed 8 April 2020. 
making the information public, China suppressed the news of the outbreak by silencing the whistle blower doctor at the inception of the crisis. Suppressing the news of the outbreak has allowed the infection to spread fast to the community level. Robert Verity et al. (2020) reported: "In international Wuhan residents repatriated on six flights, we estimated prevalence of infection of $0.87 \%$ (95\% CI $0.32-1.9$; six of 689)." ${ }^{47}$ Hence, the infection spread through not only by the "travellers from Wuhan" but also by the "panicked foreign residents" of Wuhan that were repatriated to their countries of origin. Robert Verity et al. (2020) made the following comment after presenting their data analysis results on "individual-case data for patients who died from COVID-19" in China and some other countries:

The world is currently experiencing the early stages of a global pandemic. Although China has succeeded in containing the disease spread for 2 months, such containment is unlikely to be achievable in most countries. Thus, much of the world will experience very large community epidemics of COVID-19 over the coming weeks and months. ${ }^{48}$

This prediction turned out to be true for many countries.

\section{Essential Features of Covid-19 and the Challenges Countries Face}

The Handbook of Prevention and Treatment of the Pneumonia Caused by the Novel Coronavirus (2019-nCoV) by the Tianjin Municipal Office of the Cyberspace Affairs Commission, We Doctor's Digital General Hospital and China Press of Traditional Chinese Medicine identified this novel corona virus and its features as following:

Coronavirus is a kind of virus widely existing in nature. It is the largest known RNA virus in the genome and is named coronavirus, as its form is similar to the crown under the electron microscope. [...]. It can cause respiratory tract, digestive tract, and nervous system diseases of humans and animals. [....]. So far, in addition to the new coronavirus [Covid 19], we have found six kinds of coronaviruses such like HCoV229E, HCoV-OC43, SARS-CoV, HCoV-NL63, HCoV-HKU1, and MERS-CoV that can infect humans. [....]. Pneumonia caused by the novel coronavirus was found in central China's Wuhan City, Hubei Province in December 2019. It has been proved to be an acute respiratory infectious disease caused by a new type of coronavirus. The new coronavirus is a new strain of coronavirus that has not yet been previously found in the human body. The World Health Organization named the coronavirus 2019-nCov, namely a new coronavirus. ${ }^{49}$

Xintian Xu et al. (2020) reported after studying the "Wuhan CoV (novel coronavirus) genomes":

\footnotetext{
${ }^{47}$ Robert Verity and others (n 15) 675.

48 ibid 676.

49 We Doctor Tianjin Digital Hospital (n 6).
} 
Overall, there is considerable genetics distance between the Wuhan $\mathrm{CoV}$ and the human-infecting SARS-CoV, and even greater distance from MERS-CoV. This observation raised an important question whether the Wuhan CoV adopted the same mechanisms that SARS-CoV or MERSCoV used for transmission cross species/humans, or involved a new, different mechanism for transmission.[...]. The Wuhan CoV S-protein and SARS-CoV S-protein shared an almost identical 3-D structure in the RBD domain, thus maintaining similar van der Waals and electrostatic properties in the interaction interface. [...]. Our work points to the important discovery that the RBD domain of the Wuhan CoV S-protein supports strong interaction with human ACE2 molecules despite its sequence diversity with SARS-CoV S-protein. Thus the Wuhan CoV poses a significant public health risk for human transmission via the Sprotein- ACE2 binding pathway. ${ }^{50}$

Therefore, Xintian $\mathrm{Xu}$ et al. (2020) concluded that "the Wuhan CoV S-protein is regarded to have strong binding affinity to human ACE2" $" 51$ and thus will be susceptible of human to human transmission; but the paper allowed ambiguity on this matter saying: "[a]lthough no obvious evidence of human-to-human transmission was reported, there were exported cases in Hong Kong China, Japan, and Thailand."52 It is pertinent to mention here that, from the beginning of the first few reported cases in Wuhan, China, the nature of "human to human transmission" of this outbreak was downplayed, which has resulted in the uncontrolled spread of the virus.

Vineet D Menachery et al. (2015) created a chimeric virus and reported:

Here we examine the disease potential of a SARS-like virus, [...].-Using the SARS$\mathrm{CoV}$ reverse genetics system, we generated and characterized a chimeric virus expressing the spike of bat coronavirus SHC014 in a mouse-adapted SARS-CoV backbone. The results indicate that group $2 \mathrm{~b}$ viruses encoding the SHC014 spike in a wild-type backbone can [...], replicate efficiently in primary human airway cells and achieve in vitro titers equivalent to epidemic strains of SARS-CoV. [....]. On the basis of these findings, we synthetically re-derived an infectious full-length SHC014 recombinant virus and demonstrate robust viral replication both in vitro and in vivo. Our work suggests a potential risk of SARS-CoV re-emergence from viruses currently circulating in bat populations. ${ }^{53}$ [FN omitted; Italics added]

This 2015 publication of Vineet D Menachery et al. predicted that an infection may spread from wild animals like bats to humans. ${ }^{54}$ However, this kind of publication

50 Xintian Xu and others, 'Evolution of the Novel Coronavirus from the Ongoing Wuhan Outbreak and Modeling of its Spike Protein for Risk of Human Transmission' (2020) 63(3) Science China Life Sciences 457, 458-60.

52 ibid 457.

53 Vineet D. Menachery and others, 'A SARS-like Cluster of Circulating Bat Coronaviruses Shows Potential for Human Emergence’ (2015) 21(12) Nature Medicine 1508, 1508.

54 "[T] $]$ he documented high-frequency recombination events in CoV families underscores the possibility of future emergence and the need for further preparation". ibid 1512. 
also provides knowledge for manipulation of potentially lethal pathogens of animal origin. 55

At the time of writing this article, Covid-19 is a pandemic, with no cure available. The respiratory care required for providing life saving support to Covid-19 positive patients are inadequate not only in the countries with the poor healthcare systems, but also around the entire world with a few exceptions. Countries with infrastructure and preparedness for endemic, epidemic and pandemic are able to tackle some of the unforeseeable healthcare crises but countries with poor healthcare systems are at a loss with the outbreak. China has controlled the spread of Covid-19 infection within its border in a short period of time but has failed to prevent it from spreading outside the country. Countries with top health systems in the world like the U.K. $(41,498)$ Italy $(35,473(15 \%))$, Spain $(29,011)$ and France $(30,602(26 \%))$ have counted large percentage of fatalities (of closed cases) among the Covid-19 infected population. ${ }^{56}$ At the time of this writing, the outbreak is spreading like bushfire with different the rate of fatalities in different countries but the total number of infections and deaths of closed cases $(847,126(5 \%))^{57}$ are frightening.

The search for vaccine and cure has brought to the fore the importance of:

- "investing in scientific research";

- "providing incentive to the scientists, researchers and academics" for original research; and

- "prioritizing individual States' agenda" for welfare and protection of their citizens.

Furthermore, countries have differing degrees of preparedness and abilities to fight this ever fast spreading infectious disease. Nita Madhav et al. (2018) reported:

Well-prepared countries have effective public institutions, strong economies, and adequate investment in the health sector. They have built specific competencies critical to detecting and managing disease outbreaks, including surveillance, mass vaccination, and risk communications. Poorly prepared countries may suffer from political instability, weak public administration, inadequate resources for public health, and gaps in fundamental outbreak detection and response systems. ${ }^{58}$

55 "On the basis of these findings, scientific review panels may deem similar studies building chimeric viruses based on circulating strains too risky to pursue, as increased pathogenicity in mammalian models cannot be excluded." ibid.

There should be proper evaluation of risk and gain for conducting this kind of studies that create seriously harmful pathogen. "[T]he potential to prepare for and mitigate future outbreaks must be weighed against the risk of creating more dangerous pathogens." ibid.

56 Worldometer, 'Covid-19 Coronavirus Pandemic' (10:06 GMT, August 30, 2020) <https://www.worldometers.info/coronavirus/country/spain/> accessed 30 August 2020. ibid.

58 Nita Madhav and others (n 5) 320. 


\section{The Legal Issues: An Analysis from International Law Perspective}

Article 1 of the draft articles on Responsibility of States for Internationally Wrongful Acts, 2001 of the International Law Commission (ILC) states: "Every internationally wrongful act of a State entails the international responsibility of that State." ${ }^{, 59}$ Article 2 explains the "[e]lements of an internationally wrongful act of a State" as following: "There is an internationally wrongful act of a State when conduct consisting of an action or omission: (a) is attributable to the State under international law; and (b) constitutes a breach of an international obligation of the State. ${ }^{\circ 60}$ Article 4(1) also makes it clear that " $[t]$ he conduct of any State organ shall be considered an act of that State under international law". ${ }^{61}$

Should it not be an international obligation of a State to contain a highly contagious disease? Failure of containment of Covid-19 can be understood as failure of performing the duty of State responsibility. Therefore, proper "reporting" of the outbreak may be considered as an international responsibility of the State. The pandemic of Covid-19 may:

- make the world realize the need to develop a multilateral treaty on how to deal with "infectious disease outbreak";

- propel the international community to assess, evaluate and outline the responsibility of the country of origin of outbreak and in appropriate cases, determine the liability; and

- create a platform for consensus and bring the world together.

The Covid-19 related law suits pending at different forums may provide direction and precedents for the future. However, "no-harm principle" as customary international law had been applied in many law suits ${ }^{62}$ concerning transboundary environmental harm. This principle may be invoked in different cases of transboundary harm inflicted on other States due to the failure of exercising diligence by country of the origin of the harm.

59 United Nations, 'Responsibility of States for Internationally Wrongful Acts' [2001] (2) Yearbook of the International Law Commission <https://legal.un.org/ilc/texts/instruments/english/draft_articles/ 9_6_2001.pdf> accessed 22 August 2020.

60

61

ibid. (Article 4(2) says: "An organ includes any person or entity which has that status in accordance with the internal law of the State").

62 E.g., Trail Smelter Case (United States, Canada), UNRIAA, Vol. III, pp. 1905-1982;

ICJ, Judgement, Case concerning Pulp Mills on the River Uruguay (Argentina v. Uruguay), 2010 ICJ Reports, p. 56 para.101 ("A State is thus obliged to use all the means at its disposal in order to avoid activities which take place in its territory, or in any area under its jurisdiction, causing significant damage to the environment of another State. This Court has established that this obligation "is now part of the corpus of international law relating to the environment"). 
Furthermore, Article 8 of the Additional Protocol to the Convention on Human Rights and Biomedicine, concerning Biomedical Research talks about the "[s]cientific quality" of the biomedical research and emphasized that "[a]ny research must be scientifically justified, meet generally accepted criteria of scientific quality and be carried out in accordance with relevant professional obligations and standards under the supervision of an appropriately qualified researcher." ${ }^{\text {"63 }}$ Gain of function researches should justify the scientific and ethical standard and not be openly accessible by anyone except the responsible authorities. The 2015 publication of Vineet D Menachery et al ${ }^{64}$ should have been considered as a confidential reporting.

However, Article I of the Convention on the Prohibition of the Development, Production and Stockpiling of Bacteriological (Biological) and Toxin Weapons and on Their Destruction (hereinafter the "Biological Weapons Convention"), $1972^{65}$ states:

Each State Party to this Convention undertakes never in any circumstances to develop, produce, stockpile or otherwise acquire or retain:

(1) microbial or other biological agents, or toxins whatever their origin or method of production, of types and in quantities that have no justification for prophylactic, protective or other peaceful purposes. ${ }^{66}$

If the Covid-19 is a lab-construct, then the country of the origin of this virus should be legally answerable and this Convention may direct the consequence of the outcome from the institutional investigation.

As an inter-governmental global organization and in accordance with the mandate, the World Health Organization (WHO) needed to work with the countries more actively in the beginning of this outbreak, verify information and provide answers to the key questions resonating regarding the origin of the Covid-19 pandemic. WHO affirms in the Preamble of its Constitution: "Unequal development in different countries in the promotion of health and control of diseases, especially communicable disease, is a common danger." ${ }^{27}$ Therefore, there exists high

63 Council of Europe, Additional Protocol to the Convention on Human Rights and Biomedicine, concerning Biomedical Research <https://www.coe.int/en/web/conventions/full-list/-/conventions/ rms/090000168008371a> accessed 26 August 2020.

64 Vineet D. Menachery et al., 'A SARS-like Cluster of Circulating Bat Coronaviruses Shows Potential for Human Emergence' (2015) 21(12) Nature Medicine 1508, 1508-13.

65 UNODA, Convention on the Prohibition of the Development, Production and Stockpiling of Bacteriological (Biological) and Toxin Weapons and on Their Destruction <http://disarmament. un.org/treaties/t/bwc> accessed 18 April 2020.

66 UNODA, Convention on the Prohibition of the Development, Production and Stockpiling of Bacteriological (Biological) and Toxin Weapons and on Their Destruction <http://disarmament. un.org/treaties/t/bwc/text $>$ accessed 18 April 2020.

67

World Health Organization, 'WHO Remains Firmly Committed to the Principles Set Out in the Preamble to the Constitution' <https://www.who.int/about/who-we-are/constitution> accessed 10 October 2020. 
expectation from the international community and also the member states that WHO definitely will investigate into the matter and take necessary initiatives to frame a legal instrument of state responsibility for prevention of spread of this kind of diseases.

\subsection{Law Suit in the United States against China}

Missouri State Government filed a law suit ${ }^{68}$ against the Chinese government over its improper handling of the Covid-19. Meaghan Wray reported quoting from the case document:

During the critical weeks of the initial outbreak, Chinese authorities deceived the public, suppressed crucial information, arrested whistleblowers, denied human-tohuman transmission in the face of mounting evidence, destroyed critical medical research, permitted millions of people to be exposed to the virus, and even hoarded personal protective equipment, thus causing a global pandemic that was unnecessary and preventable. ${ }^{69}$

This is not the first of its kind; this law suit is the second one. And probably many more law suits will follow regarding how this outbreak originated and the losses countries suffered from it.

\subsection{Criminal Complaint before the International Criminal Court for Crimes Against} Humanity and Genocide Against China

Freedom Watch, Inc filed a complaint at the International Criminal Court against (a) the People's Republic of China, (b) the People's Liberation Army, the official military of China, (c) The Wuhan Institute of Virology and Agency of the Government of China (d) Shi Zhengli, Director of the Wuhan Institute of Virology (e) Major General Chen Wei of China's People's Liberation Army (as defendants) alleging the release of Covid-19 from the biological laboratory (Wuhan Institute of Virology) in the city of Wuhan, China by the defendants. ${ }^{70}$ The complainant (FREEDOM WATCH, Inc.), therefore, prayed:

68 The State of Missouri v. The People's Republic of China, The Communist Party of China, National Health Commission of the People's Republic of China, Ministry of Emergency Management of the People's Republic of China, Ministry of Civil Affairs of the People's Republic of China, People's Government of Hubei Province, People's Government of Wuhan City, Wuhan Institute of Virology, and Chinese Academy of Sciences, Case: 1:20-cv-00099 Doc. \#: $1<$ https://ago.mo.gov/docs/defaultsource/press-releases/2019/prc-complaint.pdf?sfvrsn=86ae7ab_2> accessed 26 November 2020.

Meaghan Wray, 'Missouri Sues China for 'Deceit' over Coronavirus Threat' Global News (22 April 2020) <https://globalnews.ca/news/6851812/missouri-sues-china-coronavirus/> accessed 24 April 2020. 
Complainants respectfully request that the Prosecutors Office of the International Criminal Court open an investigation to determine the origins of the COVID-19 virus including its likely release from the Wuhan Institute of Virology and the Defendants' willful interference with attempts to fight the spread of the disease and develop treatments, tests, and a vaccine and once the facts alleged herein are confirmed to conduct criminal war crimes prosecutions to and try, convict and sentence to life imprisonment the Defendants herein. ${ }^{71}$

Whether the International Criminal Court can entertain this complaint as a crime against humanity and genocide against China is questionable. There are clearly given definitions and criteria for the genocide (article 6), crimes against humanity (article 7) and war crimes (article 8) in the Statute of the International Criminal Court (hereinafter mentioned as "Rome Statute") and death caused by pandemic, if found to be man-made, is not incorporated there in clear terms. ${ }^{72}$ It may require further interpretation and modification of the Rome Statute, 1998 for the International Criminal Court to entertain such complaints filed by the Freedom Watch, Inc. However, it is worth observing how the court reply to the cases on Covid-19 pandemic and if they attach any liability on China.

\section{Conclusion by Way of Recommendations}

The sewage water study report from Spain show that the virus was circulating much before the first reported case of Wuhan. This information is a game changer. So which is the country of origin of this novel corona virus? Is it Wuhan or Barcelona? It will be wise to conclude by saying that further studies may reveal more links to the origin of this virus. Amid the ambiguities regarding the origin of the outbreak, there lacks credible evidence as to the source of the pandemic, at the time of writing this article. However, China suppressed at the initial stage of the outbreak in Wuhan, two vital information essential to prevent the infectious disease from becoming a pandemic:

(i) that a novel Corona virus is spreading; and

(ii) that it is certainly positive (infectious) for human to human transmission.

Moreover, the "outbreak of an infectious disease" should be "reported" and failure to warn the international community may be considered as failure of the "State Responsibility". Therefore, the draft UN document (International Law Commission's report) on State Responsibility (Responsibility of States for Internationally Wrongful Acts, 2001) $)^{73}$ can be considered as foundation for a new "Treaty" to address the

71 ibid <https://www.freedomwatchusa.org/pdf/200416-FINAL\%20InternationalCriminalCourt Complaintsupplementdraft8.pdf $>$ accessed 10 October 2020.

72 International Criminal Court, Rome Statute of the International Criminal Court 1998 <https://www.icc-cpi.int/resource-library/documents/rs-eng.pdf> accessed 10 October 2020.

73 United Nations (n 59). 
responsibility of States on "failure of efficient reporting" of the outbreak of a highly infectious disease.

Regarding the origin of the virus, further research is needed to confirm if the "natural selection" theory is solid to justify that the virus might have jumped to humans from bats or pangolins (animal origin). A zoonotic spark causing transmission of the "pathogen of animal origin" to "human population" is not evident from the available facts.

I recommend that every State shall take certain measures to prepare itself for a pandemic outbreak and maintain certain rules of good governance relating to public health system:

- Prioritize "bio-safety" and recognize the "right to healthcare" for their population and implement it.

- Invest more public money in scientific research.

- Endemic, epidemic and pandemic preparedness is not a seasonal thing; it is rather about building the permanent facilities to tackle the unforeseeable health crisis.

- Openness, transparency and accountability are foundations of every functional State that would not export a pandemic to the world! Suppressing the news of the outbreak of an infectious disease can lead to the catastrophic consequences. Therefore, countries must practice proper reporting protocols.

- Gain-of-function research as part of biomedical researches should be carefully evaluated by the ethics committee and if approved, the bio-safety measures must be appropriate and the results should not be openly accessible by the world. Only regulatory authorities and scientific committees should have the results shared among the known, selective and responsible group of people. Declan Butler wrote quoting Simon Wain-Hobson, ${ }^{74}$ 'that the researchers have created a novel virus [SHC014; Vineet D Menachery et al. (2015)] that "grows remarkably well" in human cells. "If the virus escaped, nobody could predict the trajectory", 75

Finally, I will condense the key recommendations directly in line with Nita Madhav et al. (2018) who convincingly mentioned: "The most cost-effective strategies for increasing pandemic preparedness, especially in resource- constrained settings, consist of investing to strengthen core public health infrastructure, including water and sanitation systems; increasing situational awareness; and rapidly extinguishing sparks that could lead to pandemics.",76

\footnotetext{
74 Virologist, Pasteur Institute, Paris.

75 Declan Butler (n 14).

${ }^{76}$ Nita Madhav and others (n 5).
} 